\title{
DESENVOLVIMENTO SOCIOECONÔMICO DAS REMESSAS DE HAITIANOS MIGRANTES EM MANAUS-BRASIL
}

\author{
SOCIOECONOMIC DEVELOPMENT OF REMITTANCES OF \\ MIGRANTS HAITIANS IN MANAUS-BRAZIL
}

\begin{abstract}
Renel Fleurima
Doutorando em Estudos de Desenvolvimento Global pela Universidade Autónoma de Baja Califórnia (UABC) do México, mestre em Desenvolvimento Regional pela Universidade Federal do Amapá (UNIFAP) do Brasil, mestre em Ciências do Desenvolvimento pela Universidade Estadual do Haiti (UEH), economista em Ciências Econômicas pela Universidade Estadual do Haiti (UEH).

E-mail: renel.fleurima@uabc.edu.mx
\end{abstract}

\begin{abstract}
Resumo: Esse presente trabalho da pesquisa seguiu a lógica do percurso histórico recente dos migrantes internacionais haitianos, desde sua vivência de transformação socioeconômica e política, passando pelas motivações de seu deslocamento para outros países, como República Dominicana, Estados Unidos, Canadá e Brasil, até sua permanência nesses países. O objetivo deste artigo é analisar a migração internacional haitiana nas relações de desenvolvimento socioeconômico do Haiti durante de 2005 a 2015. Trata-se de uma pesquisa de natureza qualitativa, tendo como amostras intencionais migrantes haitianos residentes em Manaus-AM. Os procedimentos metodológicos são: revisão bibliográfica, levantamento documental e pesquisa de campo, realizada por meio de entrevistas semiestruturadas. Os resultados obtidos evidenciaram uma transformação socioeconômica por que passa a família dos migrantes devido às intervenções e à expansão das remessas derivada da diáspora haitiana.
\end{abstract}

Palavras-chave: Migrantes internacionais haitianos; Desenvolvimento socioeconômico; Manaus AM; Remessas dos migrantes; Haiti.

Abstract: This present research work followed the logic of the recent historical trajectory of Haitian international migrants, from their experience of socioeconomic and political transformation, through the reasons for their displacement to other countries, such as the Dominican Republic, the United States, Canada and Brazil, until their permanence in those countries. The purpose of this article is to analyze Haitian international migration in Haiti's socioeconomic development relations from 2005 to 2015. This is a qualitative study, with intentional samples of Haitian migrants residing in Manaus-AM. The methodological procedures are: bibliographic review, documentary survey and field research, carried out through semi-structured interviews. The results obtained showed a socioeconomic transformation that the migrant family is undergoing due to the interventions and the expansion of remittances derived from the Haitian diaspora.

Keywords: Haitian international migrants; Socioeconomic development; Manaus AM; Migrants' remittances; Haiti.

Sumário: Introdução. 1 Atividades relevantes dos haitianos migrantes. 2 Migrantes haitianos como estratégia das famílias. 3 Características das remessas dos migrantes haitianos. 3.1 Efeitos das remessas haitianas. 3.2 O impacto das remessas no Haiti. Considerações finais. Referências. 


\section{Introdução}

A migração é constitutiva do processo dos Estados nacionais (CASTLES; MILLER, 2009). Conflitos, evoluções tecnológicas e crescimento demográfico são fatores que, ao longo da história, impulsionaram a mobilidade das pessoas. Além disso, as migrações também constituíram elemento estrutural de grandes eventos da história como o colonialismo, a industrialização, a formação do mercado de trabalho para o capitalismo e, como dito, a formação dos Estados nacionais. Também se tornaram cada vez mais importantes, à medida que a globalização avança, pois, com esse fenômeno, as relações entre países aumentam, uma vez que as economias se tornam cada vez mais interdependentes. Por isso, as condições dos mercados de trabalho são modificadas, essas alterações estimulam os movimentos migratórios sobre diversas modalidades. Por outro lado, a disseminação e expansão de meios de comunicação e de transporte de passageiros estimulam a migração, produzindo várias formas de combinação entre capital e trabalho, produto desses novos fluxos de pessoas.

Nesses movimentos, não somente os trabalhadores migraram, empresas também tendem a migrar para outras cidades, onde há instalações e vantagens para terminar o processo de produção iniciado no local de origem, mas essencialmente o que é procurado são regiões inovadoras que exibam os requisitos mínimos de produção e sejam eficientes na conclusão dos bens. No entanto, dizer que as migrações são hoje um fenômeno global não se refere tanto ao volume destes movimentos que foram significativos também em outros momentos da história, mas ao fato que hoje elas interessam a quase todos os locais do Globo. Também significa que as migrações estão submetidas às transformações que os processos globais transnacionais imprimem às relações sociais, econômicas e políticas na contemporaneidade. As migrações estiveram inseridas nos contextos das outras grandes transformações de cada época (BARALDI, 2014).

Em outras palavras, com a desigualdade socioeconômica, migrar tornou-se uma necessidade, seja de empresas, capital ou pessoas em busca de melhores condições de vida e de trabalho. São elementos relevantes a desenvolver uma vocação migratória, uma vez que competir no mercado mundial significa poder penetrar nos mercados estrangeiros. E isso é válido para qualquer um dos elementos anteriormente mencionados. Não é por 
acaso que o fenômeno migratório é importante do ponto de vista econômico. Esta condição é multiplicada pelas contribuições das empresas na criação de emprego ou quando os migrantes estrangeiros são recebidos em outro país ou quando os migrantes enviam suas remessas para as empresas emissoras.

No entanto, este trabalho dedica-se a analisar, por meio das entrevistas realizadas com os migrantes haitianos na cidade de Manaus, o perfil de desenvolvimento socioeconômico do Haiti a partir das remessas enviadas. Trata-se de uma análise qualitativa, especificamente com pesquisa de campo realizada no bairro São Geraldo e no Centro Comercial de Manaus onde se localizam grandes fluxos dos migrantes haitianos.

\section{Atividades relevantes dos haitianos migrantes}

A partir do trabalho de campo realizado em diferentes momentos, entrevistando o padre haitiano Jameson Mercure, na Paróquia São Geraldo, e haitianos que vivem no bairro de mesmo nome e no Centro Comercial de Manaus, procurou-se levantar algumas informações sobre as possibilidades de trabalho informal e formal. Para além de configurar uma dupla tributação para os migrantes (uma vez que, em princípio, os seus rendimentos já foram tributados no país de residência), este objetivo pode também levá-los a optar por canais informais e sem regulação para as remessas ${ }^{1}$, gerando preocupações sobre a transparência e segurança desses fluxos.

De acordo com o padre haitiano, em Manaus, os haitianos estão localizados em diferentes bairros da cidade, entre eles da zona Centro-Sul, como São Geraldo, Chapada, São Jorge, São Raimundo e Coroado. Jameson Mercure afirmou que a maioria dos haitianos que está em Manaus trabalha no comércio (pequeno comércio) e apenas $20 \%$ deles têm empregos formais,

\footnotetext{
${ }^{1}$ Segundo o Banco da República do Haiti (BRH, 2017), as remessas de trabalhadores migrantes para o exterior estão incluídas nas transferências correntes do balanço de pagamentos (às dificuldades conceituais devemos acrescentar a omissão que uma grande parte dos canais de transferência apresenta ao controle estatístico). As transferências correntes afetam diretamente o nível de renda disponível e também o consumo de bens e serviços. Ao mesmo tempo em que elas reduzem o potencial de renda e consumo do local de onde partem, aumentam o potencial de renda e consumo do local que as recebe.
} 
e os outros fazem apenas o pequeno comércio para sobreviver e cuidar de sua família aqui (no Brasil) e no Haiti.

\begin{abstract}
Eu moro no Brasil há dois anos e oito meses e tem sido difícil viver longe da família. Para mim, o apoio da igreja tem sido fundamental pelo tempo que eu não consegui emprego, mas não fico sem fazer nada porque a igreja me ajuda para fazer alguma coisa. Muitos dos nossos irmãos precisam ajudar desse jeito porque é difícil viver aqui sem trabalhar. É a igreja que tem nos ajudado bastante, por isso estamos felizes com esse trabalho. Rubis Valery, 29 anos, chegou ao Brasil em 2015, morador do Bairro São Geraldo, (pesquisa de Campo, 2018).

Agora, eu pretendo trazer a família para ter uma moradia mais digna. A minha esposa ainda está lá no Haiti e estou fazendo de tudo para trazêla. Depois vou trazer os meus filhos. Anne Moise, 27 anos, chegou ao Brasil em 2012, moradora do Bairro Centro Comercial Manaus, (pesquisa de Campo, 2018).
\end{abstract}

O setor do mercado de trabalho que mais absorveu trabalhadores migrantes haitianos em Manaus foi o da construção civil, mas, no período da pesquisa de campo, mudou para comércio de picolés, seguido pelo comércio e serviço. Não encontrando ocupação no mercado de trabalho formal, boa parte dos interlocutores foi obrigada a aceitar atividades informais, como segurar placas de propagandas pelas ruas da cidade ou vender objetos e alimentos, como sorvete, calçado para os pés, água, camisas, seja para manauenses, seja para os próprios haitianos.

As dificuldades de encontrar trabalho no Brasil em Manaus se devem, em primeiro lugar, à saturação do mercado de trabalho local e nacional, já que a economia brasileira havia reduzido as expectativas de crescimento a partir de 2012, devido a uma crise que aconteceu. Em segundo lugar, devemse à ausência de atração de recurso econômico exigida pelo mercado, além do fator linguístico que dificulta a comunicação. Se, por um lado, não dominar a idioma português dificulta a inserção dos migrantes haitianos no mercado de trabalho, por outro, falar outras línguas, como crioulo, francês e mesmo inglês, pode abrir portas na hora de pleitear um emprego em outros segmentos laborais, como é o caso do setor de turismo local ou internacional e do ensino de idiomas.

O padre haitiano Jameson Mercure relatou que: 
como muitos haitianos que não têm empregos, reforçamos a fabricação cotidiana desse pequeno negócio de picolés para manter uma fonte de renda para os haitianos. Nós, líderes da paróquia de São Geraldo, para esta atividade comercial, vendemos a preços baixos para facilitar suas famílias a pagar o aluguel.

Se, no âmbito do mercado de trabalho, alguns desafios deverão ser superados em médio e em longo prazo, no âmbito socioeconômico, a realidade também não é diferente. No Bairro São Geraldo, onde a pesquisa se concentrou, as relações dos haitianos com o contexto local ainda são restritas e, em alguns casos, marcadas pela desconfiança e intolerância de parte dos moradores locais. Estes veem naqueles uma possível ameaça, seja por ocuparem espaços que antes eram de uso exclusivo da comunidade, como é o caso da quadra de esportes da Igreja São Geraldo, seja porque os haitianos estariam recebendo um atendimento privilegiado de parte das autoridades religiosas e civis. Nessa igreja, funciona um dos locais de atendimento da Pastoral do Migrante em Manaus e, desde 2010, tem sido a referência para a maioria dos haitianos que chegam à cidade em busca de abrigo, trabalho, orientação jurídica e religiosa, embora a maioria declare pertencer a alguma denominação evangélica. $O$ relato de o padre a seguir informa isso:

Aqui na cidade, fizemos tudo por eles, não precisamos conhecer suas crenças evangélicas ou em qual igreja eles perseveram. Nossa missão é ajudá-los na medida em que pudermos. Para alguns deles e até mesmo os manauenses que aceitaram, temos costumes religiosos na paróquia de São Geraldo, mas também todo primeiro domingo do mês adoração católica em espanhol e todo segundo domingo do mês adoração católica em francês.

Nesse contexto de transição, ser católico ou evangélico poderá ser uma estratégia de inserção num novo contexto sociocultural pautado por tradições cristãs, seja na versão do catolicismo, seja na do protestantismo. Se, no âmbito do catolicismo, há uma maior tolerância em relação às religiões, em que os adeptos transitam sem problemas entre diferentes sistemas de crenças, o mesmo não se pode dizer em relação às igrejas neopentecostais, as quais assumem uma postura de combate e negação de 
práticas alusivas ao universo religioso, demonizando-as. $\mathrm{O}$ padre Jameson Mercure relatou:

Meu irmão em Jesus Cristo, este mês de junho temos várias atividades porque é um mês do dia e de semana dos migrantes. Migrações fazem parte da história humana e podemos afirmar que todos são descendentes de migrantes que, pelas mais diversas razões, deixaram a terra natal e partiram em busca de uma vida melhor. O nosso pai na fé, Abraão, foi deles. Jacó e seus filhos migraram para Egito por causa de José. Moisés conduziu o povo numa migração que duraram quarenta anos. Nordestinos, judeus, espanhóis, libaneses, japoneses e, mais recentemente, gaúchos vieram para cá em busca de melhores condições econômicas. Hoje seus descendentes são amazônicos de fato e de direito. Trouxeram valores culturais e contribuíram para a vida econômica da região. O Amazonas acolheu a todos. Infelizmente também se repetiu aqui a injustiça e o sonho de uma terra fértil para muitos se transformou num sonho doloroso.

Nessa perspectiva, as igrejas têm tido, em geral, um papel fundamental no processo de inserção dos haitianos na cidade, sobretudo no momento da chegada, particularmente para quem não conta com a ajuda de amigos ou parentes para resolver os primeiros desafios de todo migrante: encontrar trabalho e moradia.

Outras questões, como encaminhar documentos, aprender o português, qualificar-se profissionalmente e defender direitos, são alguns dos serviços oferecidos por igrejas da cidade. Nesse sentido, a Igreja Católica tem sido um espaço de solidariedade e articulação dos haitianos num contexto marcado, às vezes, pela indiferença de governos locais e por preconceitos de brasileiros que atribuem à vinda dos haitianos ao Brasil a uma iniciativa do governo brasileiro.

Eu cheguei aqui em São Geraldo, porque tinha um amigo que morava aqui, o nome dele é Bob, ele me falou que tem uma comunidade, mas boa parte é haitiana na região de Manaus. Quando eu cheguei aqui em Manaus, de verdade, achei vários delas que já conheci na Venezuela e no Haiti, fiquei morando um tempo com Bob e outras compatriotas haitianas juntos, nós alugamos uma casa junto na primeira vez quando cheguei, depois, eu saí de casa e morei sozinho porque não pude conviver bem com eles. Mariane Alciné, 28 anos, morava na Venezuela 
em 2013 e chegou ao Brasil em 2016, morador do Bairro São Geraldo, (pesquisa de Campo, 2018).

Atualmente, os fluxos migratórios se prendem à atuação das redes sociais: os amigos e parentes que já migraram dão referências positivas do lugar àqueles que ficaram incentivando-os a migrar e construindo uma rede de relações sociais e laborais, na qual o migrante se inserirá. Previamente, já se tem garantias de emprego, mesmo seja informal, hospedagem e ajuda inicial.

\begin{abstract}
Quando estava em São Paulo, comprei uma passagem de avião para vir para Manaus, e depois fui diretamente para São Geraldo porque tinha uma prima que morava lá e me orienta. Naquela época, ela trabalhava numa empresa que precisava uma pessoa, peguei a vaga e fiquei até agora em São Geraldo. Astride Fleury, 27 anos, chegou ao Brasil em 2015, morador do Bairro São Geraldo, (pesquisa de Campo, 2018).

Eu não quero trabalhar mais na empresa, eu ganho muito mais com o comércio de Picolés. São vendidos a preços baixos e ninguém exige que paguemos quando não há venda. Eu prefiro vender os picolés em vez de trabalhar por um salário miserável. Eu constatei, as empresas exploram os migrantes haitianos porque nós não podemos reclamar. Às vezes, as empresas nos tratam com falta de respeito e nos pagam baixos salários. Não temos assistência social. Maculène Chansly, 41 anos, chegou ao Brasil em 2015, moradora do Bairro São Geraldo, (pesquisa de Campo, 2018).
\end{abstract}

Na observação de campo no Bairro São Geraldo, percebe-se, na fala dos haitianos, que a maioria está comercializando picolés. Era preciso oferecer também a oportunidade de começar uma vida nova e buscar alternativas para um futuro melhor, pois, para a grande maioria dos que aqui chegava, o único objetivo era juntar dinheiro para poder trazer a família. Tal fato tornou ainda mais urgente a necessidade de arrumar um emprego ou uma fonte de renda para garantir seu sustento.

Aqui tem problema de crise de emprego, mas, além disso, parece que as empresas têm problemas com os migrantes haitianos na questão de salários. Às vezes, a vaga está disponível, mas, quando um haitiano vai procurar e quiser negociar antes de trabalhar, a dona da empresa fala para ele que não tem mais. Jessica Sainté, 32 anos, chegou ao Brasil em 
2015, moradora do Bairro Centro Comercial Manaus (pesquisa de campo, 2018).

Os migrantes haitianos sublinham outros elementos que fazem parte da caraterização deles sobre os empregos disponíveis. Para eles, os empregos destinados aos migrantes são os mais difíceis. Existe uma forma de restrição para eles de acessar qualquer trabalho, mesmo que tenham formação acadêmica e profissional adequada para isso. Nesse ponto de vista, preferem continuar fazendo seus próprios comércios. Uma forma de enfrentar o desemprego e gerar renda, tanto para homens quanto para mulheres, tem sido vender picolés pelas ruas da cidade.

Porém, a diferença é que os picolés são fabricados por uma cooperativa organizada por eles e com o suporte logístico da Igreja São Geraldo, fato que permite ampliar a margem de lucro em cada picolé vendido. Vale notar a forma como os haitianos se apresentam ao público manauense, pois, mesmo no contexto do trabalho, eles andam bem vestidos pelas ruas da cidade. Nas observações em campo, feitas em Manaus, os migrantes haitianos que vendem picolés na rua, geralmente se vestem da seguinte maneira: homens portam, às vezes, um avental branco, denotando a assepsia na venda do picolé, e, para se protegerem contra do sol e da chuva, alguns deles levam um boné ou chapéu de cabeça também, e, em outros casos, observei também o uso de um guarda-sol. Isso denota, por um lado, a dificuldade para adaptar-se ao forte calor amazônico e, por outro, o cuidado com a pele, mesmo tendo uma cútis com uma concentração maior de melanina. No caso das mulheres, elas fazem uso de chapéus estilizados e de sombrinhas para proteger contra dor de cabeça.

Destaca-se que a questão do emprego é um elemento transversal na trajetória dos migrantes. O estatuto de migrante está fortemente ligado ao trabalho no sentido que sua disponibilidade, seu acesso, suas condições no país de origem, como no país de chegada são os elementos que vão incentivar ou não o migrante a permanecer ou ir embora para outro lugar. $\mathrm{O}$ acesso e as condições difíceis de trabalho serão um dos elementos importantes para fundamentar essa questão.

Perguntado, o padre haitiano, Jameson Mercure, no Bairro São Geraldo, sobre quais alternativas para construir a fábrica de picolés. Ele respondeu que tiveram a ideia de montá-la com o intuito de que os haitianos 
pudessem ter um aumento de renda e o que era para ser apenas um meio da vida acabou se transformando na profissão da grande maioria deles. Disse que outro padre, Valdecir, e outras pessoas começavam com a fábrica, que era um projeto pequeno,

com objetivo de gerar um ganho a mais com a venda do picolé, mas, em virtude da questão do desemprego, começou a haver essa oportunidade de renda extra, como o próprio emprego e fizeram da venda de picolé a fonte de renda deles e, graças a esse projeto, muitos conseguiram trazer seus filhos do Haiti e até alugar sua própria casa. Padre Valdecir, 56 anos, morador do bairro São Geraldo, (pesquisa de Campo, 2018).

A fábrica de picolés está instalada nas dependências do salão paroquial, funciona das $8 \mathrm{~h}$ às $18 \mathrm{~h}$ e possui cinco funcionários, tendo à frente o jovem haitiano Wilkenson Justin, que abraçou o projeto desde o seu início, em 2014, e é o responsável pela produção. A fábrica possui duas máquinas de congelamento (uma maior e outra pequena), uma batedeira, sete freezers grandes e uma câmara frigorífica para armazenamento das polpas de frutas no período de entressafras.

Saint-Vilord ou Mechand, como é mais conhecido pelos consumidores ou vendedores haitianos de picolés, gerente do restaurante nas dependências do salão paroquial, explicou que "algumas frutas aqui da região somente aparecem em determinado período, como, por exemplo, o buriti, que está dando agora, mas é preciso estocar para quando não for época não faltar”. E salientou:

Estou no Brasil desde 2014, tenho dois filhos com minha esposa e trabalhamos juntos para facilitar a melhor condição de nossa vida. Nós somos o gerente responsável deste restaurante, que funciona de dia e de noite. Durante o dia, nós cozinhamos o arroz com outros ingredientes, à noite, nós fazemos banana frita (em crioulo, fritay). Mas, muitas vezes, é a cozinha haitiana a maneira como cozinhamos. Eu devo dizer a verdade, eu cheguei antes da minha esposa no Brasil indocumentado, desde que solicitei o visto no Haiti, já que várias vezes o consulado nunca me atendeu e eu queria chegar ao Brasil, eu fui obrigado a deixar o visto para vir para o Brasil. Durante dois meses, não foi fácil, o trajeto estava pesado por causa das dificuldades econômicas e da fome. Havia muitos haitianos na viagem que perderam tudo o que tinham e até 
retornaram ao Haiti. Graças a Deus que cheguei aqui no Brasil, o trajeto foi tão longo, como Panamá, Peru e Acre e agora em Manaus, chegaram ao Brasil sem documentos. Todos os meus recursos foram gastos nesta viagem, eu não posso te dizer o quanto esta viagem me custou, mas, se não me engano, havia cerca de US \$2.000,00. Mas hoje eu estou feliz por poder recuperar o dinheiro que eu gastei graças a este restaurante que nos trouxe muito. Saint-Vilord, 44 anos, chegou ao Brasil em 2014, morador do bairro Centro Comercial Manaus (pesquisa de Campo, 2018).

No caso dos haitianos em Manaus, pode ser muito cedo para tirar conclusões sobre o processo de integração na cidade, mesmo que seja um fluxo migratório recente com alta taxa de rotatividade, porque, para muitos destes, a cidade tem sido um sucesso, devido às motivações para entrar no mercado de trabalho e comércio local. Para outros, a migração para países como os Estados Unidos tornou-se outra opção menos atraente, apesar do alto investimento e risco que tal decisão acarreta. Para quem fica na cidade, pode ser o lugar de realização de transformações socioeconômicas, trocas culturais e religiosas e também para realização suas vidas pessoais e em família.

\section{Migrantes haitianos como estratégia das famílias}

Na nossa perspectiva, o desenvolvimento socioeconômico é definido como uma transformação e melhoria de recursos, maneira pela qual um migrante ou uma sociedade aloca meios limitados para a satisfação de necessidades numerosas e ilimitadas no sentido socioeconômico. E, com referência aos migrantes internacionais haitianos, exige participação ativa. Torna-se, assim, um conceito dinâmico para representar atividades econômicas ou produtivas geradoras de renda, realizadas individualmente ou pessoalmente.

É também a melhoria de vida familiar dentro de uma sociedade. Associadas ao desenvolvimento socioeconômico dos migrantes internacionais, há ainda as ações para melhorar as condições de produção de suas famílias nos países de origem. Incluem-se os fatores que sustentam esse desenvolvimento nos níveis econômico, político e social. Neste estudo, o desenvolvimento socioeconômico é medido de acordo com o exercício da 
atividade econômica e o envio de recursos financeiros. $\mathrm{O}$ envolvimento socioeconômico torna-se, assim, um meio para que as famílias dos migrantes em seus países de origem tenham acesso a um maior bem-estar, proporcionando maior integração social.

Segundo Abdelmalek Sayad (1999), é difícil estabelecer vantagens da migração (haitiana) para fins do desenvolvimento, uma vez que fatores não controláveis estão envolvidos e é um processo que, dependendo do tipo de migrante, pode ser considerado com recurso inovador, mas também varia de acordo com os migrantes envolvidos, que criam fontes de emprego nos países aonde chegam ou aqueles que são incorporados na estrutura ocupacional do país de residência.

Do ponto de vista conceitual, a migração internacional se vincula à ideia de Estados nacionais, materializando-se por meio do cruzamento das fronteiras políticas destes (CASTLES, 2009). Assim, as migrações internacionais só acontecem porque existem as fronteiras. Juridicamente deveriam constituir a exceção no sistema de Estado-Nação, que se constrói sobre a tríade: governo, povo e território, em que um povo estável (ou estabilizado), localizado em um território definido, é ligado a um governo e a um ordenamento jurídico que possui jurisdição (poder) sobre aquele território. O migrante é aquele membro de um Estado que se desloca para outro território e, portanto, coloca-se sob a jurisdição desse outro Estado.

Esses movimentos, no entanto, nunca foram exceção, o que revela o caráter excludente do Estado-Nação em sua origem (SAYAD, 1999; BAENINGER, 2013). A diferenciação entre nacionais e não nacionais cada vez menos se justifica diante da internacionalização dos direitos humanos, através da institucionalização e da regulamentação internacional destes, principalmente a partir da segunda metade do século XX.

A questão da migração internacional haitiana também é constituída por um número crescente de pessoas que saem do país: em 2015, cerca de 1,2 milhão de haitianos viviam no exterior, ou quase $11 \%$ da população. $\mathrm{O}$ Gráfico 1 e a Tabela 1 que apresentam uma visão sobre o fluxo dos migrantes haitianos e também sua distribuição para países desenvolvidos e países em desenvolvimento.

O Haiti é um país do Caribe em uma área de $27.750 \mathrm{~km}^{2}$. A sua população em 2015 foi estimada em 10,5 milhões de habitantes, constituindo os dez departamentos da região, Noroeste, Norte, Nordeste, Artibonite, 
Centro, Oeste, Sudeste, Nippes, Sul e Grande-Anse. Em 2005, o número de migrantes era próximo de 1 milhão (correspondendo a 10,4\% da população). É importante destacar que a instabilidade política, a opressão econômica e/ou as catástrofes naturais contribuíram para a configuração de novos fluxos migratórios.

Gráfico 1 - Número dos migrantes internacionais haitianos, 2005-2015

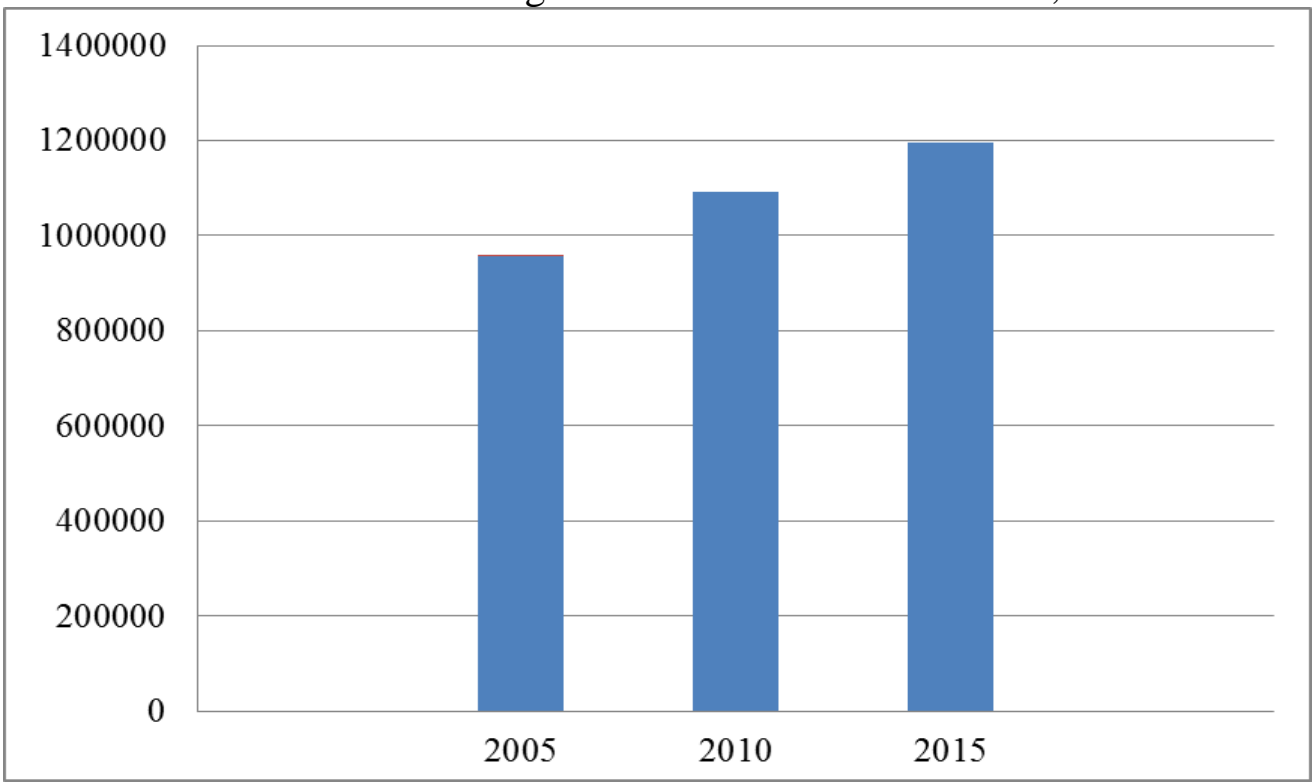

Fonte: DAES (2015), organizado pelo autor (2018)

A maioria dos haitianos está em países desenvolvidos, embora a porcentagem de migrantes haitianos nos países em desenvolvimento tenha aumentado ao longo do tempo, constituindo novos polos do espaço internacional haitiano, como Brasil e Chile, depois da tragédia do terremoto ocorrido em 2010.

Tabela 1 - Migração internacional haitiana para países desenvolvidos e em desenvolvimento

\begin{tabular}{cccc}
\hline Anos & $\mathbf{2 0 0 5}$ & $\mathbf{2 0 1 0}$ & $\mathbf{2 0 1 5}$ \\
\hline Total & 957722 & 1092025 & 1200940 \\
\hline $\begin{array}{c}\text { Países desenvolvidos } \\
\text { Países em desenvolvimento } \\
\begin{array}{c}\text { Porcentagem de vida em } \\
\text { países desenvolvidos (\%) }\end{array}\end{array}$ & 617857 & 702804 & 870662 \\
\hline
\end{tabular}

Fonte: DAES (2015), organizado pelo autor (2018) 
Cerca de 300 mil haitianos são vítimas do terremoto que optaram por migrar na América Latina e região do Caribe. Bahamas, Cuba, Curaçao, St. Thomas, República Dominicana, Brasil e Chile estão entre os países de destino onde os haitianos são mais marginalizados (MARCELINO, 2013; OCDE e INURED, 2017).

Os migrantes poucos qualificados, muitas vezes indocumentados, ficam extremamente vulneráveis nos países aonde chegam, uma vez que são frequentemente vítimas de violação dos direitos humanos e trabalhistas. Embora a vulnerabilidade dos migrantes entre os haitianos não seja nova, nos últimos anos, essa situação se tornou cada vez mais complexa. Por exemplo, muitos migrantes haitianos foram atraídos para o Brasil. No entanto, devido a recentes crises políticas, econômicas e sociais que passa este país, alguns daqueles que já estavam aqui se mudaram para outros destinos na América do Sul e no Caribe, enquanto outros embarcaram em viagens terrestres perigosas, incluindo a fronteira entre Estados Unidos da América (EUA)-México e outros desafios migratórios (MARCELIN, 2017).

Em 2013, a desnacionalização de pessoas de origem haitiana na República Dominicana colocou mais de 130 mil pessoas em risco de ser apátridas, 76\% das quais eram crianças (OCDE e INURED, 2017; UNICEF, 2016). Menos de um mês após a decisão do tribunal dominicano, mais de 50 mil pessoas de origem haitiana foram deportadas da República Dominicana.

Entre junho de 2015 e dezembro de 2016, cerca de 160.452 (cento e sessenta mil quatrocentos e cinquenta e dois) pessoas cruzaram a fronteira entre a República Dominicana e o Haiti, das quais 2.551 (duas mil quinhentos e cinquenta e um) foram identificadas pela Organização Internacional para as Migrações (OIM) como menores não acompanhados (UNICEF, 2016). Os relatórios sugerem que as pessoas mais vulneráveis e indocumentadas não receberam ajuda dos governos dominicanos ou haitianos.

A situação especial dos haitianos na República Dominicana e o fato de que esses dois países compartilham uma fronteira em grande parte porosa têm empurrado as organizações de direitos dos migrantes no Haiti a se dedicarem ao trabalho de defesa dos direitos humanos e do trabalho. As deportações periódicas em larga escala de haitianos de vários países das Américas ilustram a deterioração dos princípios básicos dos direitos humanos (HANDERSON; MARCELIN, 2017), em particular para os 
migrantes pobres, uma vez que a marginalização econômica na era da globalização os obriga a se moverem.

\section{Características das remessas dos migrantes haitianos}

Apesar do crescente interesse pela temática das remessas e maior popularização do conceito entre estudiosos e formuladores de políticas, ainda não há consenso quanto à sua conceituação. Não há conceituações que esclareçam o termo de forma a dar conta de sua complexidade e variedade no que tange às transferências. Economistas associam as remessas geralmente a itens do balanço de pagamentos. Já as remessas dos trabalhadores são ligadas ao conceito de recursos e refere-se às transferências correntes de estrangeiros que permaneceram ou pretendem permanecer por um período de pelo menos um ano em determinado país.

Além disso, devem ser adicionados a este registro dois outros aspectos que também dizem respeito a remessas de dinheiro: a remuneração de funcionários - dinheiro que as pessoas ganham para trabalhar fora do país em que vivem formalmente (por exemplo, um emprego sazonal ou em que o empregado se desloca diariamente); transferências de migrantes - são os recursos que os migrantes trazem consigo quando se deslocam de um país para outro.

Antes de abordarmos os principais elementos que caracterizam a importância das remessas de migrantes internacionais haitianos, bem como seu contexto de produção e de circulação, é necessário resgatar, mesmo que brevemente, o histórico, ainda recente, dos estudos sobre remessas, de modo a justificarmos algumas de nossas opções teóricas e metodológicas em torno deste tema. Para compor este breve histórico, optamos por apresentar a historiografia das remessas proposta por Luís Felipe Aires Magalhães (2017) e Rosana Aparecida Baeninger (2013), por adotarem estes autores em uma posição teórica e metodológica próxima à da nossa perspectiva.

Todavia, o seu esforço de categorização não substitui o próprio esforço de síntese e sistematização de toda a literatura sobre remessas a qual não cabe aqui desenvolvermos, tendo em vista os objetivos próprios, razão pela qual não abrimos mão de sempre indicar a autoria da categorização e sublinhar possíveis divergências em relação a ela. 
As remessas de migrantes constituem, desde 2003, a principal forma de entrada de recursos externos na América Latina, competindo com os investimentos das multinacionais (Investimento Estrangeiro Direto, IED). São inúmeros os indicadores de sua importância para os países do continente: no Haiti, representam $150 \%$ das exportações do país e oscilaram entre $22 \%$ e $26 \%$ do PIB nacional nos últimos dez anos. Em Honduras, representam $25 \%$ do PIB do país. Representam entre $15 \%$ e $20 \%$ do PIB na Jamaica, El Salvador, Nicarágua e Guatemala. Representam entre 5\% e 10\% do PIB em países como Belize, Equador, Granada e a própria República Dominicana (MAGALHÃES, 2017; BAENINGER, 2013).

Segundo a Comissão Econômica para a América Latina e o Caribe (CEPAL, 2009), as remessas de migrantes atenuam as desigualdades sociais e promovem a saída de milhões de famílias no Brasil e na América Latina abaixo da linha da pobreza, passando a viver sob as condições mais favoráveis (MAGALHÃES, 2017). A diminuição do volume das remessas de migrantes, como consequência da crise, em um contexto de dependência de remessas, funciona como um estímulo às famílias migrantes, no caso haitiano, a procurarem novos destinos migratórios.

Parece-nos significativo que, no Haiti, entre 2005 e 2015, o valor das remessas (como porcentagem do PIB do país) tenha atingido seu menor nível em 2007, ano do início da crise capitalista, e apenas tenha recuperado o patamar anterior à crise em 2010, ano em que a migração haitiana encontra o Brasil. Especialmente desde 2012, as remessas como porcentagem do PIB do Haiti voltaram a apresentar tendência de crescimento.

Inicialmente, é importante compreender que as remessas de migrantes são responsáveis por financiar parte significativa do consumo corrente das famílias receptoras e que são fundamentais também para que as economias latino-americanas e caribenhas, dependentes que são, possam aliviar ou mesmo equilibrar o déficit em seus balanços de pagamentos, através de superávits na conta transferências unilaterais, promovidos pela entrada destes recursos. Do exposto, entende-se que uma diminuição das remessas de migrantes, conforme diagnosticado pela Cepal (2009), traz efeitos perversos para milhões de famílias que as recebem, constituindo-se em uma forma de contágio da crise capitalista aos países receptores. Essa conjuntura guarda, certamente, relação com a redefinição dos fluxos migratórios, mas, para investigar mais a fundo como que a dinâmica das migrações internacionais pode ser condicionada pela diminuição das remessas e pelo 
agravamento das tensões migratórias, é importante definirmos precisamente a situação de dependência de remessas por parte das famílias (e economias) receptoras de remessas, particularmente no Haiti.

O conceito de dependência de remessas (MAGALHÃES, 2013; BAENINGER, 2016) não se refere, propriamente, a uma análise otimista e funcionalista destes recursos, tal como apresentado pelos organismos internacionais, particularmente ONU e Cepal, mas sim a uma interpretação mais ampla do tema, relacionada às condições de trabalho que originam as remessas e às condições sociais e econômicas nas regiões das famílias no país de origem em que as remessas são consumidas, realizadas.

Segundo essa interpretação dos autores, as remessas representam a forma concreta de articulação entre as questões sociais e econômicas distintas. Esta articulação integra, ainda, o trabalhador migrante no país de destino e sua família, no Haiti. O valor de reprodução da força de trabalho é significativamente inferior - o que explica, em essência, a própria existência da remessa. A dependência de remessas é um conceito que expressa a necessidade crescente que algumas famílias envolvidas no processo migratório têm dos recursos enviados por familiares migrantes (BINFORD, 2002). Essa dependência está relacionada à forma com que esses recursos são utilizados. Nesse sentido, as famílias serão dependentes à medida que tais recursos sejam predominantemente utilizados para o consumo, a subsistência, o pagamento dos gastos correntes com alimentação e educação, por exemplo.

As remessas funcionariam, então, como um mecanismo de expansão do consumo das famílias de origem, desencadeando uma relação de dependência por parte dessas famílias em relação a esses recursos, ou seja, constituindo a já citada dependência de remessas. O acréscimo no nível do consumo, por seu turno, amplia as necessidades materiais dessas famílias. A ausência de estruturas produtivas inclusivas no país faz com que essa expansão no nível de consumo, ou mesmo a sua manutenção, seja possível apenas com o afluxo de novas remessas, o que concretamente tende a significar a emergência de novos fluxos migratórios internacionais de outros familiares que permaneciam no país (Haiti).

Consideramos que a migração contribui para o desenvolvimento social e econômico, ao menos no âmbito local, onde há efeitos diretos e indiretos das remessas enviadas pelos migrantes internacionais haitianos, estruturando a atividade econômica local das famílias de modo tal que a 
incidência da migração internacional futura desacelere. Ou seja, os investimentos das remessas - ou os efeitos indiretos de seu desembolso provêm a base para condições de trabalho humanas e um nível de remuneração suficiente para sustentar um modo de vida digno.

Numerosos domicílios individuais e a maioria dos domicílios em inúmeras comunidades ricas têm usado o dinheiro das remessas para ascender socialmente, ao menos por certo tempo. Porém, um número elevado de domicílios e de comunidades não tem sido beneficiado. Essa situação tende a favorecer novas migrações, a fim de proporcionar a base para um nível de vida que somente pode ser mantido graças a um fluxo constante de remessas (BINFORD, 2002).

Em maio de 2018, em sua apresentação na Universidade Quisqueya (UNIQ), Charles Castel, ex-presidente do Banco da República do Haiti, enfatizou o impacto positivo das remessas privadas recebidas do exterior para o Haiti. Argumentou que as remessas, aumentando a renda disponível e reduzindo a pobreza nos estratos sociais haitianos, aliviam a pressão sobre o Estado, disse Charles Castel, destacando que as remessas certamente ajudam a diminuir as diferenças sociais. Ele afirmou que as remessas também proporcionaram a aplicação de recursos em educação, um setorchave para o desenvolvimento, bem como de capital para microempreendedores no setor de serviços. Destacou ainda a importância das remessas para as questões de educação, moradia, alimentação e microempresas.

Durante seu discurso, Castel salientou que as remessas de dinheiro da diáspora haitiana tendem a aumentar quando há catástrofes no Haiti: ciclones, terremotos, entre outros. Mesmo em 2008, ano marcado por uma grande crise bancária e financeira, as remessas permaneceram estáveis, afirmou Charles Castel, sinalizando os esforços e sacrifícios feitos pelos parentes na diáspora que apoiam suas famílias no Haiti.

No Haiti, as remessas são direcionadas para o consumo. Segundo Charles Castel, o desafio agora é redirecionar as remessas para outros eixos. Orientar remessas para poupança e investimento é outro desafio para o Haiti, disse. Nos primeiros quatro meses de 2018, as remessas privadas recebidas do exterior aumentaram em 30,94\% do PIB, afirmou Castel. Para explicar a importância das remessas, Charles Castel disse que uma renda nacional de US \$ 700, no Haiti, não é suficiente para o sustento de uma família. Um bilhão de dólares por ano, diz ele, é a quantia que o Estado consegue gerar. 
As remessas devem ser capitalizadas para equilibrar os gastos públicos e investimentos que permitem ao país ser mais competitivo. As remessas de dinheiro da diáspora atingiram em 2017 a quantia de três bilhões de dólares norte-americanos. Elas contribuem para preencher parcialmente uma lacuna na balança comercial do país (Relatório elaborado pelo autor, 2018, durante palestra do ex-presidente do BRH sobre as remessas, na Universidade Quisqueya). Existem poucos estudos que abordam as consequências econômicas e sociais das remessas dos trabalhadores migrantes internacionais haitianos para suas famílias no seu país e a desigualdade socioeconômica naquele Estado. O montante de remessas enviadas ao Haiti pelos migrantes aumentou todos os anos durante 2005-2015, o que atraiu meu interesse em estudar a temática.

Neste trabalho de artigo, apresentamos alguns elementos para entender quais são as consequências dessa chegada de remessas sem contrapartida, a situação de pobreza e desigualdades que caracterizam a sociedade haitiana. Embora as expectativas macroeconômicas em relação às remessas para algumas famílias sejam benéficas, minha análise mostra que é melhor ser mais cauteloso ao prever as possíveis consequências dessas remessas dos migrantes haitianos na economia e na sociedade haitianas.

Além disso, um país como o Haiti não pode depender apenas dos efeitos das remessas, devido aos grandes problemas enfrentados, nem mesmo a população local. As remessas não estimulam o desenvolvimento sustentável nem melhoram a economia do país a fim de encontrar recursos para competir com os produtos importados, que desencorajam os investidores locais. Não são suficientes para reduzir a inflação tão rapidamente quanto aumenta a migração internacional haitiana. Charles Castel, em sua palestra sobre as remessas dos migrantes haitianos, leva em conta o desenvolvimento social e econômico das famílias individuais e coletivas, mas isso não promove o bem-estar do Estado haitiano.

Pudemos perceber com base nos dados sobre as remessas de 26 migrantes haitianos entrevistados no bairro São Geraldo e no Centro Comercial de Manaus que esses recursos são destinados e utilizados efetivamente para o consumo e a subsistência das famílias no Haiti. No âmbito da teoria sobre as remessas de migrantes, essa utilização não pode ser desprezada ou ignorada: trata-se de famílias que desenvolvem relação de dependência com essas remessas. A Tabela 2 explica as remessas dos migrantes haitianos constatando a sua regularidade. 
Ratificando a reflexão de Castel, o resultado obtido durante a pesquisa de campo sobre o impacto das remessas no país de origem foca os seguintes temas: impacto sobre a repartição do rendimento; a redução da pobreza; o bem-estar individual; efeito das remessas sobre a economia nacional; as incidências sobre o emprego, a produtividade e o crescimento; papel das remessas na cobertura dos déficits da balança comercial e da balança das operações correntes. $\mathrm{O}$ peso das remessas é importante, mas é a sua utilização que mais interessa.

Tabela 2 - Envio de remessas aos familiares que permanecem no Haiti

\begin{tabular}{lc}
\hline Remessas de migrantes & Total \\
\hline Enviam & 24 \\
Não envia & 1 \\
Não respondeu & 1 \\
Total & 26 \\
\hline
\end{tabular}

Fonte: Dados da pesquisa (2018)

Porém, para os países em desenvolvimento como o Haiti, as migrações internacionais e diásporas haitianas são componentes da realidade nacional, mais dinâmica do que os fluxos de investimento direto estrangeiro, de comércio ou de tecnologia. As remessas constituem uma importante fonte de capitais para esses países e uma fonte de divisas mais estável do que outros fluxos de capitais privados. Tanto as remessas utilizadas para fins de consumo como para investimento trazem benefícios às famílias no país de origem, bem como às populações haitianas que as recebem. Devem ser feitos esforços para que as remessas dos migrantes impactem o desenvolvimento econômico e social.

É predominante a realização de remessas, mesmo sob as duras condições do mercado de trabalho em que atuam os haitianos e os gastos elevados com aluguel no país de chegada. Alguns dos entrevistados enviam todo dia 5 de cada mês e também duas vezes por mês, remessas no valor de $\mathrm{R} \$ 1.000,00$ e 1.500.00 para as famílias e os filhos que ficaram no Haiti. Boa parte deles possui dois empregos. As entrevistas revelaram, ainda, que as remessas não chegam a ultrapassar $\mathrm{R} \$ 2.000,00$, como mostra a Tabela 3, e que o valor monetário mais comum é o de envio de até $\mathrm{R} \$ 600,00$ para manter a regularidade. 
Meu pai mora em Miami, EUA, e minha mãe, no Haiti. Migrei quando ainda era criança. Eu tenho um filho pequeno que fica com minha família, especificamente minha mãe, no Haiti. É uma família cujos membros vivem em três países diferentes (Estados Unidos, Brasil e Haiti). A tradição de migração para os Estados Unidos foi quebrada por mim, porque migrei para o Brasil por dificuldades de entrada e emprego de migrantes para os Estados Unidos, o que faz uma grande diferença no nível de remessas. Jean-Renand Blaise, 28 anos, chegou ao Brasil em 2013, morador do Bairro Centro Comercial Manaus, (pesquisa de Campo, 2018).

A migração para o Brasil, nesse contexto, é mais do que um projeto individual: é uma estratégia familiar para manter a subsistência, dificultado pela intensificação da crise econômica e social pós-terremoto. Uma estratégia que expressa a falta de garantias e de perspectivas de reprodução social no Haiti e a migração se dá na busca dessas garantias e perspectivas em outros países.

Tabela 3 - Valor das remessas dos haitianos entrevistados no Bairro São Geraldo e no Centro Comercial

\begin{tabular}{lc}
\hline Valor & Total \\
\hline Até R\$ 600,00 por envio & 12 \\
De R\$ 600,01 a R\$ 1.000,00 por envio & 7 \\
$\begin{array}{l}\text { De R\$ 1.000,01 a R\$ 1.500,00 por } \\
\text { envio }\end{array}$ & 4 \\
$\begin{array}{l}\text { De R\$ 1.500,01 a R\$ 2.000,00 por } \\
\text { envio }\end{array}$ & 2 \\
Mais de R\$ 2.000,00 por envio & 0 \\
Não envia remessas & 1 \\
Total & 26 \\
\hline
\end{tabular}

Fonte: Dados da pesquisa (2018)

Como se vê, na mesma tabela citada que contém os valores enviados pelos migrantes, relativamente poucas remessas são gastas em investimento, em grande parte devido à capacidade limitada dos beneficiários das famílias para empreender e gerenciar atividades produtivas, por um lado, e à falta de confiança de migrante em estruturas intermediárias, por outro lado. Esses dois fatores explicam em grande parte as dificuldades encontradas pelos projetos-piloto que buscam desenvolver investimentos produtivos dos migrantes internacionais haitianos. 
$\mathrm{O}$ significativo potencial que as remessas representam para $\mathrm{o}$ desenvolvimento socioeconômico levou alguns países, como o Haiti, a colocar em prática mecanismos de alavancagem para incentivar os migrantes a dedicar parte de suas remessas a fundos de atividades cotidianas. Outros criaram instrumentos financeiros específicos para absorver parte das remessas, complementá-la com recursos financeiros de fontes públicas e facilitar as condições de vida entre migrantes e órgãos de desenvolvimento da produtividade. Em uma entrevista, Wadner Mesidort diz:

Eu vim da cidade de Leogane, no Oeste, moro no Brasil há dois anos, mas minha família ainda está no Haiti e temos quatro filhos. Eu gosto daqui porque me apaixonei pelo país. Como eu já conheço alguns haitianos sei também que os mesmos gostam do nosso Brasil. Eu, desde que cheguei aqui, trabalho já, porque minha responsabilidade é tão pesada, meu amigo, quando eu saio para outros países não posso escolher muito, tenho que trabalhar duro para ajudar minha família no Haiti. No passado, eu costumava enviar dinheiro duas vezes por mês por causa de minha atividade como moderada e, às vezes, eu trabalhava como técnico de alvenaria no Estádio de Manaus. Meu amigo, eu posso te dizer que o Brasil é um país que eu amo tanto, aqui eu estou trabalhando dia e noite para ganhar dinheiro e ajudar a minha família, muitas vezes eu mandei $\mathrm{R} \$ 1.400,00$ por mês mesmo duas vezes, agora não é tão fácil de fazer isso, como o real diminuiu em relação ao dólar, isso me dificultou consideravelmente, mas é um compromisso enviar para a minha esposa para que ela não trabalhe e minha mãe é uma viúva. Mas, em princípio, francamente vou levar a nacionalidade brasileira para facilitar o privilégio, já entramos no processo de naturalização, não preciso ir aos Estados Unidos para trabalhar, já que fiquei muito bem no Brasil. Trarei toda a minha família aqui por causa de nossa participação como diáspora na vida cotidiana de nossa família. Eu não sei para outras pessoas, mas eu me naturalizo. Wadner Mesidort, 34 anos, chegou ao Brasil em 2016, morador do Bairro São Geraldo, (pesquisa de Campo, 2018).

Independentemente se os motivos migratórios são políticos, econômicos ou culturais, o cerne de alguns fatores é a capacidade de inserção social do meio envolvido, no sentido de envolvimento de cidadãos e migrantes, em estruturas que são significativas e asseguram a consecução de objetivos socialmente definidos (PIERRE, 2014). Nesse sentido, o emprego, a proteção social e os laços interpessoais de tipo étnico ou comunitário formam esses protótipos de estruturas. A relação entre migração 
e desenvolvimento socioeconômico é afetada de forma diferente pela capacidade de organizar a integração social dos indivíduos, especialmente no que tange a um emprego estável e protegido, que gere renda suficiente para dar garantia de um padrão de vida satisfatório.

A complexidade da relação entre migração e desenvolvimento econômico se prende a uma série de parâmetros, como o sucesso migratório, a natureza da migração e a manutenção de vínculos entre migrantes e as pessoas que ficam no país de origem. A migração é bem-sucedida quando os migrantes podem se integrar em estruturas significativas. Esta inserção pode depender do grau de abertura do país de chegada, do status do migrante, bem como do fato de serem ou não qualificados e do contexto histórico.

Como vimos, no caso do grupo migrante haitiano: as remessas são enviadas exclusivamente para o sustento da família, e utilizadas, por sua vez, apenas para financiamento de consumo, educação e agricultura (e, em menor medida, para gastos com moradia dos familiares). Não há qualquer menção, seja na finalidade do envio, seja propriamente na utilização das remessas, de investimento econômico e social, produtivo ou financeiro, destes recursos.

A dualidade entre consumo e investimento é particularmente importante no estudo das remessas porque ela não se refere apenas às opções e escolhas tomadas pela família, mas também, e principalmente, às suas necessidades mais urgentes, as quais são condicionadas por sua posição na estrutura econômica e social do Haiti. Em outras palavras, a forma de utilização das remessas é uma expressão da estratificação socioeconômica no Haiti. É justamente nos domicílios mais pobres que as remessas são utilizadas prioritariamente para o sustento.

Tabela 4 - Forma de envio das remessas pelos migrantes haitianos entrevistados no Bairro São Geraldo e no Centro Comercial de Manaus

\begin{tabular}{lc}
\hline Forma de utilização das remessas pela família & Total \\
\hline Consumo familiar & 18 \\
Moradia de dependentes & 1 \\
Investimento econômico & 1 \\
Investimento em educação para dependentes & 6 \\
Total & 26 \\
\hline
\end{tabular}

Fonte: Dados da pesquisa (2018) 
A regularidade no envio das remessas também é um elemento presente no cotidiano dos migrantes haitianos residentes no Bairro São Geraldo e Centro Comercial de Manaus e de suas famílias no Haiti.

Tabela 5 - Regularidade de envio das remessas mensais dos migrantes haitianos entrevistados no Bairro São Geraldo e no Centro Comercial de Manaus

\begin{tabular}{lc}
\hline Há regularidade no envio de remessas? & Total \\
\hline Sim & 22 \\
Não & 3 \\
Não respondeu & 1 \\
Total & 26 \\
\hline
\end{tabular}

Fonte: Dados da pesquisa (2018)

Os migrantes que têm a obrigação de enviar dinheiro mensalmente ou que não enviam regularmente mantêm relações sociais fortes e próximas com seus membros familiares no Haiti. Por outro lado, aqueles que transferem dinheiro anualmente preferem pertencer a um relacionamento familiar fraco ou estendido com o Haiti, a menos que seja a persistência do desemprego que os obriga a fazer apenas uma transferência por ano no caso contrário.

Complementando as questões que envolvem as tabelas (4 e 5), Maxo Bonhomme relatou:

Acabei de encontrar emprego (eu estava desempregado há três meses, desde o fechamento de meu negócio), recebendo $\mathrm{R} \$ 1.330,00$ líquidos em meu trabalho de operador de estoque em uma empresa da cidade. Além disso, pago mensalmente $\mathrm{R} \$ 455,00$ para o aluguel do meu quarto sem janela, aproximadamente $10 \mathrm{~km}$ do Centro Comercial de Manaus. $\mathrm{O}$ que resta deve ser economizado todo mês para que eu possa arcar com minhas despesas. É possível enviar fundos de até $\mathrm{R} \$ 700,00$ para minha família no Haiti.

Ao fazer essa emergência, sei o quanto esse valor é importante para a necessidade básica da minha família. Para isso, envio esses recursos. Maxo Bonhomme, 38 anos, chegou ao Brasil em 2011, morador do Bairro São Geraldo, (pesquisa de Campo, 2018). 
Maxo Bonhomme e todos os migrantes haitianos interlocutores informaram que realizaram remessas para o sustento de suas famílias no Haiti. Nenhum deles afirmou ter tido o propósito de compra de imóvel, carro ou abertura de um negócio. O Merilien Fred prosseguiu:

Agora estou fazendo esse pequeno negócio porque não tenho trabalho, mas não vou continuar. Eu ganho muito mais nas atividades do meu trabalho, já que temos que pagar o aluguel e as outras necessidades que são as causas fundamentais que me obrigam a entrar nesse negócio. Apesar de eu não ganhar muito dinheiro, a responsabilidade é muito grande, minha esposa está comigo, há duas crianças no Haiti para cuidar, tenho que enviar dinheiro todo mês. Merilien Fred, 47 anos chegou ao Brasil em 2012, morador do Bairro Centro Comercial Manaus, (pesquisa de Campo, 2018).

Quando indagada se a Sra. Anita Massillon acredita que participa do desenvolvimento social e econômico do Haiti, ela respondeu prontamente:

\begin{abstract}
Absolutamente, sim. Devo dizer-lhe, todos os outros haitianos que deixaram o país cumprem com suas responsabilidades para com suas famílias no Haiti. Eu estou aqui há cinco anos, mas minha esposa tem três anos. Estamos dispostos a trazer nossos filhos. Anita Massillon, 39 anos, chegou ao Brasil em 2013, mora a $10 \mathrm{~km}$ do Centro Comercial de Manaus, (pesquisa de Campo, 2018).
\end{abstract}

A fala dessa migrante explicita algumas dificuldades que passam, afirmando que não consegue encontrar um emprego, já que o objetivo fundamental de deixar o seu país era trabalhar para assumir a responsabilidade pelas despesas de sua família e filhos que estão no Haiti à espera de recursos financeiros. Conforme relata Joceline Fleury:

Na verdade, o Haiti não nos ofereceu nada. Eu sempre agradeci a Deus por me ajudar a deixar o Haiti há 13 anos. Eu não vim para o Brasil antes, vivi 11 anos na Venezuela. A crise política e econômica me obrigou a vir para o Brasil. Eu tenho uma casa na Venezuela e eu vim com a minha filha, outro filho que tenho ficou com a minha mãe lá. Eu viajo para a Venezuela a cada dois a três meses para visitar minha família porque a maioria dos meus bens está lá. Eu sempre estou falando 
sobre o Haiti, porque meus irmãos e irmãs ficaram. No entanto, quando eu estava na Venezuela, mandava dinheiro para eles com muita frequência. Agora, no Brasil, ainda é diferente porque não trabalho, é do comércio que vivo o que fez diminuir a transferência. Preocupo-me muito com eles por causa da situação econômica e social do Haiti. Estou sempre ajudando eles, ainda que não frequentemente, como quando estava na Venezuela. Enviei apenas R \$ 600,00 em torno de dois a três meses por falta de trabalho aqui no Brasil. Joceline Fleury, 25 anos, chegou ao Brasil em 2016, morador do Centro Comercial de Manaus, (pesquisa de Campo, 2018).

Embora recentemente conhecido, nos últimos anos um conjunto de trabalhos tem especificamente chamado a atenção para diferentes aspectos sociais e simbólicos presentes no uso de remessas, além de sua dimensão estritamente econômica, atribuindo especial importância ao contexto social em que são recebidos remessas e o papel dos fatores socioculturais no comportamento econômico.

A Tabela 6 mostra que as finalidades para as quais as remessas são enviadas pelos migrantes haitianos nem sempre correspondem à forma como são utilizadas pelos familiares residentes no Haiti. Os interlocutores, quanto a esse quesito, puderam responder com mais de uma opção a esse questionamento.

Tabela 6 - Finalidade do envio de remessas no Haiti

\begin{tabular}{lc}
\hline $\begin{array}{l}\text { Finalidade do envio das remessas ao país de } \\
\text { origem }\end{array}$ & Total \\
\hline Sustento da família & 24 \\
Compra de imóvel & 1 \\
Compra de automóvel & 0 \\
Abertura de negócio & 1 \\
Total & 26 \\
\hline
\end{tabular}

Fonte: Dados da pesquisa (2018)

Com base nessas informações, percebemos que as remessas são utilizadas pelas famílias dos migrantes haitianos para o sustento delas e financiamento de educação de dependentes de migrantes. Sendo assim, as condições materiais e de vida são completamente transformadas, minimizando a pobreza no Haiti. No entanto, essas remessas haitianas, as migrações e o desenvolvimento socioeconômico são reavaliados de forma mais otimista e positiva, com um enfoque de negação da possibilidade de 
que essas remessas possam trazer efeitos sociais e econômicos perversos, como os já descritos. Liliane Mercius ressalta as qualidades do Brasil:

Sempre ouvi dizer que o Brasil é um país cheio de oportunidades e que amam estrangeiros. Eu nunca estive em outro país, viajei diretamente para o Brasil, mas aqui percebi que é a realidade que eu pensava desde o Haiti. Todo mês pelo menos mandava $\mathrm{R} \$ 805,00$ para minha família, especialmente para minha mãe, já que ainda não tenho filhos. O povo brasileiro é acolhedor. O brasileiro não tem que te conhecer para te ajudar, acho muito interessante. Liliane Mercius, 23 anos, chegou ao Brasil em 2015, morador do Bairro Centro Comercial Manaus, (pesquisa de Campo, 2018).

Observações são muito explícitas também sobre as recomendações das famílias no Haiti, que querem uma mobilidade social para os seus filhos fora do país. Esses elementos foram percebidos no relato dos interlocutores.

\begin{abstract}
Minha chegada ao Brasil foi motivada por várias razões, o Haiti não tem muitas oportunidades... Um dia tive uma conversa com meu pai e ele me disse: "fillho, olha, faz tempo que cada eleição eu voto e continuo a votar na esperança de uma transformação econômica e social que nunca vai acontecer. Então, se você ficar no Haiti, você vai viver a mesma realidade que eu. Eu vi que muitas pessoas vão para o Brasil ou Chile e outros países e já começam a ajudar as famílias três meses depois. Acho que seria melhor para você e para nós se você puder ir também". Fiquei um tempo, finalmente, quando vi que o Haiti é parado na "luz vermelha", tentei vir para o Brasil, escutando os conselhos do meu pai. Efetivamente hoje, graças a Deus, envio dinheiro para eles e ajudo a pagar a universidade para minha irmã. Rosemond Altidort, 26 anos, chegou ao Brasil em 2015, morador do Bairro São Geraldo, (pesquisa de Campo, 2018).
\end{abstract}

Nesse trabalho, foi possível perceber a emoção que sente o migrante ao ganhar dinheiro e ter condições de enviar mensalmente recursos ao Haiti. Demonstram satisfação em participar ativamente de algumas atividades de familiares residentes naquele país, como o interesse deles pelo aprendizado universitário de membros de sua família, uma vez que acreditam na importância do conhecimento intelectual. 
Eu tenho dois filhos aqui no Brasil, moro com minha família. Antes morava na Venezuela, desde 2010, razão política e econômica me obrigaram a vir para Manaus em 2015. Estou sempre em contato com meus parentes no Haiti. Meu pai faleceu e, por isso, não consigo esquecer-se de minha mãe e envio um pouco de dinheiro para ela. Sou do departamento de Artibonite no Haiti. Veronise Cadet, 25 anos, chegou há cinco anos à Venezuela e três anos ao Brasil, moradora do Centro Comercial de Manaus, (pesquisa de Campo, 2018).

Essas remessas haitianas, as migrações e o desenvolvimento socioeconômico são reavaliados de forma mais otimista e positiva, com um enfoque de negação da possibilidade de que essas remessas possam trazer efeitos sociais e econômicos perversos, como os já descritos.

Sendo assim, apreende-se uma análise sobre os efeitos produtivos dessas remessas, ainda que a maior parte delas seja utilizada para o sustento (BAENINGER, 2013; MAGALHÃES, 2017). Por meio delas, dá-se impulso ao comércio, ao setor de serviços, ao sistema bancário da região, entre outros, o que acarreta desenvolvimento econômico e social, incentivando atividades de investimento produtivo. Por fim, este enfoque inaugura o debate sobre a relação entre consumo e investimento nas formas de utilização das remessas.

Tenho dois filhos, mas devo dizer a verdade: eu estava na Faculdade de Direito e Economia no Haiti, onde estudei ciências da economia. A situação era muito difícil no Haiti. Depois de completar os estudos, estou no Brasil somente para trabalhar, já que meus dois filhos não estão me acompanhando, um deles está no Haiti e o outro está com a mãe dele aqui no Brasil. Moro com outra mulher. Não me arrependo de estar no Brasil, trabalho dia e noite para ajudar meus filhos e minha mãe, já que ela não trabalha mais. Verlot Joseph, trabalha no aeroporto na companhia aérea, 33 anos, chegou ao Brasil em 2013, morador do Bairro Centro Comercial Manaus, (pesquisa de Campo, 2018).

Verlot Joseph, durante a entrevista, ressaltou que tinha apenas cinco minutos para fazer uma transferência de mil dólares reais $(\mathrm{R} \$ 1.000)$ para $\mathrm{o}$ Haiti, mas destacou que considera a sua participação no desenvolvimento socioeconômica naquele país é muito ativo. 
Podem-se destacar como possíveis efeitos positivos das remessas a atenuação das desigualdades, o incremento nos investimentos produtivos e a diminuição da pobreza nos países receptores destes recursos.

\begin{abstract}
No Haiti, eu estava em uma dificuldade dolorosa porque eu fiz uma graduação na universidade, mas não consegui encontrar trabalho, razão central que me obrigou a deixar meu país. Recebi visto do Haiti para chegar a Manaus. No Brasil, minha experiência é boa, porque eu não estava trabalhando no Haiti, agora tenho a possibilidade de enviar dinheiro para minha família, sou muito jovem, depois, tendo concluído um estudo aqui, pretendo voltar ao Haiti. Tichard Verson, 34 anos, chegou ao Brasil em 2015, morador do Bairro São Geraldo, (pesquisa de Campo, 2018).
\end{abstract}

Como pesquisador haitiano, posso afirmar que a maioria dos haitianos que saiu do país o fez para encontrar melhores condições de vida, assim como atender necessidades sociais, educacionais e outras necessidades básicas. Alguns entrevistados relataram que suas condições de vida melhoraram completamente após a saída do Haiti. Outros estão desempregados e o motivo de sua vinda para o Brasil foi o futuro incerto que os aguardava naquele país. Essas situações se repetem nas entrevistas e na transformação econômica e social pela qual passam suas famílias no Haiti devido ao envio das remessas.

\title{
3.1 Efeitos das remessas haitianas
}

É importante enfatizar a relevância das remessas dos migrantes internacionais haitianos para o desenvolvimento socioeconômico do Haiti, destacando o papel que eles podem desempenhar como capital humano para a educação, investimentos imobiliários, entre outros. No entanto, as remessas são usadas principalmente na compra de alimentos e outros bens de consumo para a família que permanece no Haiti.

Pode haver uma evolução no uso de fluxos financeiros, que, como disse, são inicialmente aplicados nas despesas de consumo primário individual ou da família, na transformação da vida precária, satisfazendo as necessidades imediatas de consumo. Dá-se ênfase também aos benefícios 
reais ou potenciais para o desenvolvimento socioeconômico do país, derivado da contribuição que os migrantes destinam ao financiamento de suas famílias haitianas. Sendo assim, a maior parte das remessas de migrantes haitianos ainda é gasta em consumo são de valor inestimável, pois suprem as necessidades básicas e amenizam a pobreza das suas famílias no Haiti. Os migrantes são a esperança de suas famílias.

Cabe ressaltar que os fluxos financeiros iniciados pelos cidadãos haitianos altamente qualificados contribuem para o desenvolvimento socioeconômico subjacente à migração internacional e à diáspora haitiana (Observatório ACP sobre as migrações, 2014. Doura Fred, 2010) salienta que as remessas realizadas por migrantes haitianos representam mais de 50\% do produto interno bruto do país [...] e podem ter um efeito preponderante no país de várias maneiras: 1) como entradas de capitais estrangeiros, esses envios ajudam a financiar o déficit comercial, melhorando assim a situação da balança de pagamentos do país; 2) em países de baixa e média renda, esses recursos aumentam a renda daqueles que os recebem [famílias], reduzindo diretamente a pobreza e ajudando a preservar os padrões de consumo doméstico, contribuindo indiretamente para estabilizar a atividade econômica do país (PNUD, 2005). Além disso, um estudo de Gupta (2007), em uma amostra de 76 países, aponta um aumento de $10 \%$ nas remessas em relação ao PIB, o que leva a uma redução de $1 \%$ na taxa de pobreza (PIERRE, 2014; DOURA, 2010).

Essas remessas podem suprir, em maior ou menor grau, as necessidades de consumo da família que ficou no país de origem, cuja renda monetária é frequentemente baixa e instável. Destarte, ao aumentar os rendimentos e diversificar suas fontes, os recursos dos migrantes contribuem para melhorar a vida cotidiana das famílias, auxiliando-as na superação das situações de crise econômica.

Alguns estudos sobre essas remessas indicam que as famílias que as recebem têm um padrão de vida mensal mais alto do que a média nacional. Bénédique Paul (2008) também afirma que, segundo estimativas, cerca de 95\% das remessas transferidas de migrantes haitianos são utilizadas nas despesas de consumo da família no país de origem, assim como para cobrir os custos de saúde e educação, vestuário, aluguel e aquisição de itens domésticos e necessidades urgentes do consumidor (DOURA, 2010; HEIN, 2010). As remessas para o Haiti também podem ser usadas para construir ou adquirir uma casa ou terreno. Ressaltamos que o investimento em educação 
ou saúde, por outro lado, melhora o capital humano do país e, portanto, tem um efeito sobre a sua produtividade em longo prazo, na medida em que essa capital permanece no país.

As remessas dos migrantes haitianos também podem financiar pequenas e médias empresas, comércio ou pequenos projetos de infraestrutura locais. O consumo aumenta a demanda por produtos locais, onde a oferta é elevada, ou seja, a produção doméstica responde positivamente a uma crescente demanda por bens e serviços, ao mesmo tempo em que controla o aumento dos preços. Esses recursos oriundos dos haitianos repatriados podem, nesse caso, desempenhar um papel importante para os consumidores haitianos, pois contribuem para o crescimento econômico e, consequentemente, para a promoção de empregos e investimentos no país. O Haiti, por meio de políticas econômicas, multiplica essas remessas advindas da diáspora geralmente nos países em que os migrantes se encontram (PIERRE, 2014).

Essas remessas migratórias haitianas representam uma forma de proteção, segurança contra incertezas e precariedades por que passam os familiares que permanecem no país. A migração de mão de obra também permite aliviar a concorrência no mercado de trabalho nacional, diminuindo assim as tensões ligadas à falta de postos nesse mercado. Além disso, os rendimentos da migração podem estimular a atividade econômica local e, de certa forma, substituir o crédito e outras formas de financiamento que muitas vezes são inacessíveis às populações pobres e mal adaptadas às suas necessidades. No entanto, os fatores que levaram as pessoas a migrar também são muitas vezes aqueles que limitaram o potencial produtivo das remessas. No entanto, a falta de serviços públicos do Estado haitiano e de infraestrutura limita severamente as potencialidades produtivas das remessas.

\subsection{O impacto das remessas no Haiti}

Existe uma predominância de padrões de consumo em relação à acumulação e ao aumento das importações, que contribui para a elevação do déficit comercial. A satisfação dos novos padrões de consumo geralmente implica um aumento nos bens importados, o que, por sua vez, compensa o 
impacto positivo das remessas de migrantes nas reservas cambiais. As remessas migratórias são substituídas pela oferta de mão de obra e, como já explicitadas, são importantes para a renda familiar no país de origem, mas seu impacto na produção agrícola e na produtividade também é bastante significativo.

No Haiti, as remessas podem afetar a agricultura, uma vez que proporcionam às famílias a oportunidade de manter o mesmo nível de renda, reduzindo a oferta de mão de obra. Esse fenômeno, que pode ser descrito como benéfico, surte também efeitos na contramão do crescimento da produção agrícola. Isso porque, ainda que as remessas proporcionem a compra de equipamentos agrícolas, as famílias que recebem esses recursos decorrentes da migração internacional atingem níveis de produção significativamente menores que as famílias locais que não contam com essa ajuda.

As remessas representam uma forma de seguro, afirma Flore Gubert (2003). Os países que recebem grandes quantidades de remessas (o que equivalente a $4 \%$ a $31 \%$ do PIB), segundo o Banco Mundial (2006-2007), assim como o Haiti, geralmente modificam suas taxas de câmbio, taxas de juros e saldo de pagamentos. Segundo Doura (2010), a entrada maciça de remessas da diáspora é suscetível de desencadear uma sobrevalorização da taxa de câmbio real com consequente perda de competitividade - preço.

Essas remessas, aliadas à assistência externa, contribuem para as ações do Estado haitiano na mobilização dos diferentes componentes do espaço orçamentário, como recursos públicos (receitas fiscais e não fiscais), e também influenciam o financiamento alternativo (empréstimos internos, criação de empresas). Isso, por sua vez, pode levar a sonegação de receitas fiscais referentes a essas remessas e também certas negligência da gestão pública e privada. O efeito inflacionário resultante dessa demanda não é comum ao resto da população que não recebe recursos do exterior.

Essas remessas da diáspora haitiana podem provocar inflação na economia do país, causando especulação nas transações de compra e venda de terrenos para a construção de casas e/ou para investimento do capital. Muitas vezes, as propriedades são supervalorizadas, custa de duas a quatro vezes o valor econômico real (PAUL, 2008; DOURA, 2010; PIERRE, 2014). Essa especulação afeta significativamente o setor imobiliário, provocando o aumento do preço dos materiais de construção e uma elevação dos preços de aluguel. Esses recursos geram uma propensão ao consumo e a 
altos gastos, o que, por sua vez, prejudica os consumidores locais que não conseguem acompanhar o aumento de preços. As remessas acabam substituindo outras formas de renda, em vez de complementá-las, criando uma forma de assistência e dependência da família no país de origem em relação aos trabalhadores migrantes.

Hein de Haas (2010), ao tratar de remessas de migrantes, busca aproximar este tema da materialidade das relações capitalistas de produção e aponta que a esfera de circulação das remessas de migrantes possui duas etapas: a etapa internacional, na qual as remessas circulam entre os países e são catalogadas no Balanço de Pagamentos do país de onde o migrante partiu e do país aonde chegou; e a etapa nacional, em que as remessas chegam às famílias no país de origem e compõem uma dinâmica econômica, social e demográfica específica, particular, daquela região que as recebe.

É importante entender cada uma dessas etapas, com suas peculiaridades envolvendo um mesmo e indissociável processo - a circulação das remessas. A etapa internacional da esfera de circulação das remessas de diáspora é aquela em que os volumes das remessas são mais visíveis, dado que, para circular internacionalmente, necessitam ser registrados, catalogados no Balanço de Pagamentos dos países envolvidos nesta remessa. Nessa etapa, portanto, apresentam-se mais claramente os fluxos de remessas da diáspora haitiana e os países mais envolvidos nesse circuito de remessas. As remessas de migrantes não permitem necessariamente reequilibrar as finanças de suas famílias em todos os aspectos em nível nacional, mas podem reduzir as dificuldades socioeconômicas, em particular as locais causadas pelo desemprego ou subemprego no setor agrícola. Além disso, não permitem resultados decisivos no que tange à renda internacional ou a redução de desigualdades salariais entre países de origem e países de chegada.

As remessas dos migrantes haitianos internacionais geralmente ajudam a diversificar alguns recursos e também a aumentar substancialmente a renda de suas famílias no Haiti. Desempenham um papel crucial funcionando como seguradoras contra os efeitos desestabilizadores dos mercados que se comportam de forma disfuncional, políticas nacionais ineficientes e inadequação dos benefícios sociais ofertados pelo Estado. Um estudo da OIM (2005) aponta que, em nível nacional [no Haiti], as remessas são uma fonte de moeda estrangeira maior, menos volátil, improdutiva e 
representam fluxos de capital mais confiáveis para os países em desenvolvimento.

Uma vez que a migração, incluindo a haitiana, é um processo rigoroso, a maioria das remessas internacionais não beneficia os membros mais pobres das comunidades no meio rural e urbano ou dos países mais pobres. No entanto, as famílias não migrantes geralmente se beneficiam indiretamente do impacto do envio de dinheiro na economia local, pois afeta os salários, os preços e as oportunidades de emprego nas comunidades do país de origem. Sendo assim, o envio de remessas contribui para a redução da pobreza, ao menos em parte. Remetemo-nos aqui à obra do economista indiano Amartya Sen (2010), sobre o desenvolvimento como liberdade para compreender os aspectos socioeconômicos do Haiti, uma vez que o autor considera a noção de liberdade como o principal vetor de desenvolvimento, em particular, a liberdade individual para escolher o estilo de vida que se pretende ter.

Tal perspectiva orientada para o desenvolvimento sugerida por Sen (2010) se concentra nas capacidades individuais e coletivas. O autor destaca que o acesso à educação, aos serviços de saúde, a condição de ter alimentos, remédios etc. são produtores de liberdade, bem como projetos comunitários voltados para a educação, saúde e recreação, uma vez que contribuem para o bem-estar dos indivíduos e fortalecem suas capacidades socioeconômicas. Para operacionalizar essas independências, apresenta o conceito de desenvolvimento humano, que se refere à capacidade dos seres humanos de viver a vida que querem por razões particulares e de aperfeiçoar as escolhas que fazem das opções que lhes são ofertadas. Argumenta que o desenvolvimento não deve ter como critério decisivo o crescimento da renda e $\operatorname{sim}$ as capacidades individuais. Nesse sentido, as possíveis mudanças na vida dos migrantes dependem do tipo de migração, bem como das condições socioeconômicas do país de origem. A Tabela 7 reproduz os montantes relativos a transferências de dinheiro feitas por migrantes haitianos internacionais para os membros de sua família que permanecem no Haiti período de 2005 a 2015. 
Tabela 7 - Montante de transferências em dólares americanos por migrantes haitianos de 2005-2015

\begin{tabular}{lccc}
\hline Anos & $\begin{array}{c}\text { Transferências } \\
\text { recebidas }\end{array}$ & PIB & $\begin{array}{c}\text { Transferências em } \\
\text { \% de PIB }\end{array}$ \\
\hline $\mathbf{2 0 0 5}$ & 670.943 .892 .56 & 4.154 .289 .832 & $16.151 \%$ \\
$\mathbf{2 0 0 6}$ & 776.041 .933 .23 & 4.879 .738 .636 & $15.903 \%$ \\
$\mathbf{2 0 0 7}$ & 892123.792 .94 & 5.971 .284 .338 & $14.940 \%$ \\
$\mathbf{2 0 0 8}$ & 997.150 .939 .70 & 6.407 .707 .284 & $15.562 \%$ \\
$\mathbf{2 0 0 9}$ & 1.004 .149 .216 .97 & 6.470 .254 .240 & $15.519 \%$ \\
$\mathbf{2 0 1 0}$ & 1.075 .396 .201 .52 & 6.634 .579 .143 & $16.209 \%$ \\
$\mathbf{2 0 1 1}$ & 1.133 .491 .277 .73 & $7.346 .156,703$ & $15.430 \%$ \\
$\mathbf{2 0 1 2}$ & 1.177 .118 .016 .84 & $7.843484,458$ & $15.008 \%$ \\
$\mathbf{2 0 1 3}$ & $1.929 .601 .291,52$ & $9.188 .577 .578,7$ & $21 \%$ \\
$\mathbf{2 0 1 4}$ & 1.954 bilhão & $8.495 .652 .173,9$ & $23.02 \%$ \\
$\mathbf{2 0 1 5}$ & 2.057 bilhões & 8.228 .000 .000 & $25 \%$ \\
\hline
\end{tabular}

Fontes: Banco da República do Haiti (2017), organizado pelo autor (2018)

No entanto, esse enorme influxo de dinheiro melhorou significativamente a economia haitiana. Os fluxos de remessas, portanto, contribuíram para elevar o volume de transações ${ }^{2}$ financeiras (OROZCO, 2005). Além disso, as Transferências Financeiras de Migrantes Haitianos (TFMH) levaram os intermediários financeiros a desenvolver uma oferta mais ampla de serviços de remessas no país.

Esse aumento nas transações financeiras e econômicas em termos sociais, em geral, também contribui para a criação de riqueza no país. Para as famílias beneficiárias, o valor recebido é um aumento da renda familiar, para o país, pode contribuir para o agravamento das desigualdades de renda no Haiti. Um elemento importante que nos interessa particularmente nesta pesquisa é o aumento das transações e, mais especificamente, o microcrédito, em relação aos migrantes internacionais no Haiti. Embora as

\footnotetext{
${ }^{2}$ A transação de remessas envolve um conjunto de custos de transação para o remetente e os destinatários. Frédéric Ponsot (2006) mostra, entre outras coisas, as despesas de viagem até o ponto de serviço (recepção/despacho), os custos de prospecção para a busca de tarifas e pontos de serviço nas proximidades, perdas em divisas e o custo de encontrar bens, bem como melhores taxas para embarques de moeda flutuante, custos de comunicação para comunicar montantes e códigos de identificação, papelada e documentos de suporte necessários, tempo de espera no balcão para completar a transação (envio/recebimento).
} 
TFMHs sejam muito seletivas, a transferência de alguns desses recursos para organizações locais de microfinanças permite que outras pessoas sejam beneficiadas na comunidade por esse dinheiro (PAUL, 2008). A partir disso, as organizações de microfinanças - $\mathrm{OMFs}^{3}$ entram neste novo mercado criado em função das diásporas haitianas. Em 2004, foi transferido 7,3 milhões de dólares norte-americanos através da filial bancária Fonkoze, a maior organização de microfinanças do Haiti. De fato, mesmo que as OMFs sejam tomadoras de preços em tarifas, elas podem ajudar a reduzir os custos de transação no mercado de remessas de diáspora. Além disso, elas podem fornecer uma resposta mais adequada à natureza informal dos ambientes regionais que se beneficiam dos fluxos de remessa.

A maioria dessas remessas é voltada a consumo e poupança, sendo apenas 5\% dos montantes enviados investidos na economia haitiana (OROZCO, 2008). O envio instantâneo das remessas de dinheiro facilitou e acelerou o processo. Juliana Braz Diaz (2010), analisando os fluxos utilizados para as campanhas da rede social do Western Union, mostra que essas remessas carregam muito mais do que valor econômico. Com o envio e recebimento de dinheiro, as relações familiares e de amizade são fortalecidas e reconfiguradas, mantendo o lugar de cada um na estrutura social ou outorgando-lhe novos significados.

A reflexão apresentada sobre as remessas de migrantes internacionais haitianos ao país acentua a natureza da migração. As famílias com um status socioeconômico privilegiado que recebem remessas de dinheiro muitas vezes preferem investir na partida de outro membro da família do que em uma atividade econômica. Quanto às outras famílias não beneficiárias, a principal saída da crise econômico-financeira é o envio de um membro da família para o exterior, a migração.

\footnotetext{
3 Preferimos a expressão "Organizações de Microfinanças" (daí a sigla OMF) em vez de "Instituições de Microfinanças" (IMF), que, embora já seja consolidado na literatura, não levam em conta os avanços teóricos da economia neoinstitucional, bem como teorias de gestão. De fato, para o economista Douglass North bem como para outros teóricos e estudiosos de gestão, a distinção é clara entre organizações e instituições.
} 


\section{Considerações finais}

Neste artigo, pudemos analisar as origens históricas e recentes do processo migratório haitiano em que foi identificada a formação histórica dos fatores que motivam a saída de cidadãos do Haiti e refletimos sobre alguns dos principais fluxos históricos da migração internacional haitiana, como República Dominicana, Estados Unidos. Países tão distintos, econômica e socialmente, motivaram-nos a analisar fluxo numa perspectiva histórica e de forma particular na transformação da vida das famílias. Esta foi também a motivação para a análise do fluxo migratório haitiano no Brasil, particularmente em Manaus.

No entanto, na República do Haiti, a migração é motivada por fatores econômicos e políticos. Esses migrantes internacionais haitianos ajudam os membros da família que permanecem no país e contribuem para o sustento das necessidades básicas, fazendo transferências significativas de recursos econômicos, que representavam cerca de um quarto do PIB do país em 2015. $O$ papel desempenhado pelos migrantes na reconstrução e no desenvolvimento social e econômico do Haiti foi destacado após o terremoto de 2010, quando o governo e os atores internacionais, assim como as potencialidades, contribuíram financeiramente e também compartilharam seus conhecimentos num esforço de reconstrução do país.

Porém, em nenhum momento constatamos que existe uma relação de causa e efeito entre as intervenções estratégicas do Estado e o processo de deslocamento dos migrantes internacionais haitianos para os países estrangeiros. O fenômeno migratório haitiano começou a produzir, desde o início do século XX, efeito cultural, político, social e econômico, com implicação direta no Estado. Nessa dinâmica, a migração haitiana foi apresentada como uma das expressões de transformação socioeconômica da família no Haiti. Alguns fatos também são dignos de nota: diferentemente do que está acontecendo em muitos países da América e do Caribe, o Estado haitiano nunca considerou o custo pago pelos migrantes internacionais para enviar dinheiro ao Haiti para suas famílias permaneceram lá. Nenhum estudo nacional compara preços de transferência ou faz recomendações.

Se, desde 2010, o Estado haitiano especificamente cobra toda contribuição dos migrantes, não há transparência sobre o assunto. Também não existe nenhum plano articulado para integrar as remessas à economia 
nacional. Os migrantes pagam suas contas, seu consumo, arcam com suas dificuldades, mas não têm o reconhecimento de que seu dinheiro contribui para o desenvolvimento do país.

\section{Referências}

AUDEBERT, C. La diaspora Haitienne: territoires migrations et réseaux transnationaux, PUR, Campus de la Harpe, 2012.

BAENINGER, R. Migração internacional - Estudos de População, Campinas: Núcleo de - Nepo/Unicamp, 2013, p. 36.

Migração Transnacional: elementos teóricos para o debate. In: Imigração Haitiana no Brasil. Jundiaí: Paco Editoral, 2016.

BARALDI, C. B. F. Migrações Internacionais, Direitos Humanos e Cidadania Sul-Americana: o prisma do Brasil e da Integração Sulamericana. Tese apresentada ao Programa de Pós-Graduação em Relações Internacionais do Instituto de Relações Internacionais da Universidade de São Paulo, 2014, p. 15.

Banque de la République d'Haiti (BRH). Les transferts de la diaspora représentent 25\% du PIB d'Haïti en 2015.

Banco Mundial. Haïti, les Défis de la Lutte contre la Pauvreté. Banque de la République d'Haïti: Rapport Annuel, 2014.

BECKER, G. Théorie du Capital Humain, New York, Columbia University Pres, 1964.

BINFORD, L. Remesas y Subdesarrollo en México. Revista Relaciones, Benemérita Universidad Autónoma de Puebla, nº 90, v. XXIII, Primavera 2002. p. 116-158.

CANALES, A. Elementos para una teoría de las migraciones en el capitalismo global. Guadalajara: M.A Porrúa Y Universidad de Guadalajara, 2015. 
CASTleS S.; MILlER, M. The Age of Migration. International Population Movements in the Modern World, 3e édition, Macmillan Press Ldt., Londres, 2009.

DAES. Département des affaires économiques et sociales des Nations Unies. Trends in International Migrant Stock: Migrants by Destination and Origin (United Nations database, POP/DB/MIG/Stock/Rev.2013). World Urbanization Prospects, 2013-2014.

DOURA, F. Economie d'Haiti dépendance-crises et développement; Les éditions DAMI, 2002, p. 225.

Haiti: histoire et analyse d'une extraversion dependante organisee. Montreal, Les Editions DAMI, 2010, p. 173.

GUBERT, F. Migrations du Sud et reduction de la pauvreté: des effets ambigus pour les pays de départ, in E.M. Mouhoud (dir.) Les Nouvelles migrations, Universalis, Paris, 2006.

HANDERSON, J. Diáspora, circulação e mobilidade: jovens haitianos no brasil. Les Jeunes Haïtiens dans les Amériques, Presses de l'Université du Québec, Québec, 2017.

HEIN de Haas. Migration et développement: Une perspective théorique. Version traduite d'un article publié sous sa forme finale dans International Migration Review, 2010.

MAGAlHÃES, L. F. A imigração haitiana em Santa Catarina: perfil socio demográfico do fluxo, contradições da inserção laboral e dependência de remessas no Haiti. Campinas, 2017.

Migração Internacional e Dependência na Divisão Internacional do Trabalho: um estudo da região sul de Santa Catarina. Campinas, 2013.

MARCELIN, L. E. Interactions entre politiques publiques, migrations et développement en Haïti, Les voies de développement, Éditions OCDE, Paris, 2017.

MARCELINO, P. F. Si Proches et Si Lointaines: Les diásporas haïtiennes aux Caraïbes. Organisation internationale pour les migrations, Bruxelles, 2013.

NOUVELLISTE. Les transferts d'argent de la diaspora vers Haïti ont augmenté en 10 ans. Publié le 2017-06-21 | Le Nouvelliste, 2015. 
OIM. Organisation Internationale pour les Migrations Migration en Haïti: profile migratoire nationale 2015. Port-au-Prince, Haiti, 2015.

OROZCO, M. Remittances and MFI intermediation: issues and lessons. in Remittances, Microfinance and Development: building the links, Judith Shaw editor, The Foundation for Development Cooperation, 2005.

PAUL, B. Comment sortir Haïti de la dépendance vis-à-vis de l'aide internationale? Une proposition basé sur l'entrepreneuriat innovation: Haïti Perspectives, no1, Printemps 2012.

PIERRE, A. Migration Haïtienne Etat des lieux sur une problématique, Port-au-Prince, 2014, p. 29.

SAYAD, A. O retorno: elemento constitutivo da condição do imigrante. Travessia - Revista do Migrante, ano XIII (número especial), 2000.

SEN, A. Desenvolvimento como liberdade. Tradução Laura Teixeira Morta. São Paulo: Companhia das Letras, 2010.

SILVA, S. A. Haitianos em Manaus: mercado de trabalho e exercício da cidadania. Em busca do Eldorado: O Brasil no contexto das migrações nacionais e internacionais. Manaus: Edua, 2016.

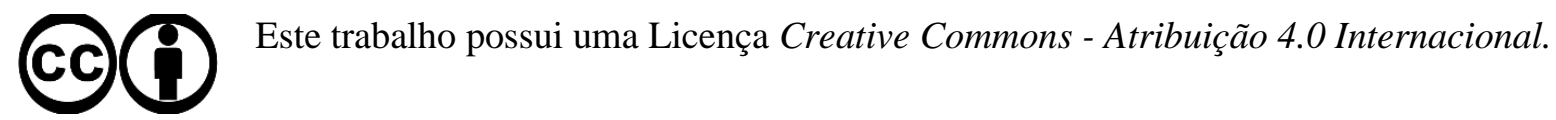


Como citar este artigo (ABNT)

FLEURIMA, Renel. Desenvolvimento Socioeconômico das Remessas de Haitianos Migrantes em Manaus-Brasil. Revista Semestral de Direito Econômico, Porto Alegre, v. 01, n. 01, e0106, jan./jun. 2021. https://doi.org/10.51696/resede.e0106

Recebimento: 03/01/2021

Avaliação preliminar: 03/01/2021

Aprovação: 10/05/2021

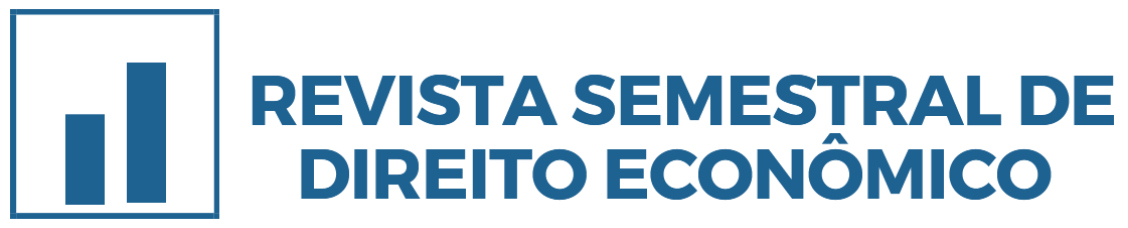

